\title{
Profil Kompetensi Pedagogik dan Profesional Mahasiswa Calon Guru Fisika
}

\author{
Fatma Hamid $^{1 \star}$, Saprudin ${ }^{2}$ \\ 1,2 Program Studi Pendidikan Fisika, Universitas Khairun \\ Jalan Bandara Babullah, Ternate, Maluku Utara \\ *E-mail: fatmahamid@unkhair.ac.id
}

\begin{abstract}
Abstrak
Penelitian ini merupakan suatu survei yang bertujuan untuk menggambarkan profil kompetensi pedagogik dan profesional mahasiswa calon guru fisika (MCGF). Survei ini melibatkan 60 MCGF yang berada pada semester VI sampai semester VIII pada tahun akademik 2015-2016 pada salah satu LPTK di Ternate, Indonesia. Pengumpulan data dilakukan dengan menggunakan instrumen tes untuk mengukur kompetensi guru dan studi dokumentasi. Berdasarkan hasil analisis data, ditemukan bahwa kompetensi pedagogik dan kompetensi profesional MCGF masih dikategorikan rendah dengan rerata persentase sebesar $34,0 \%$ dan $25,8 \%$. Hasil survei ini diharapkan dapat menjadi acuan dalam merumuskan tindakan yang tepat terkait peningkatan kompetensi pedagogik dan profesional MCGF pada lokasi penelitian.
\end{abstract}

Kata kunci: Profil kompetensi, Kompetensi Pedagogik, Kompetensi Profesional

\begin{abstract}
This research is a survei that aims to describe the profile of pre-service physics teachers (PPT)' pedagogical and professional competencies. This survei was involved 60 PPT for the sixth semester to eighth semester on the 2015-2016 academic year in the physics education study program at a LPTK in Ternate, Indonesia. Data was collected through teacher competency tests and documentation studies. The results of the data analysis showed that the PPT' pedagogical and professional competencies can be categorized as low with a percentage of $34.0 \%$ and $25.8 \%$. The results of this survei are expected to be used as a reference in formulating appropriate actions related to improving the PPT' pedagogical and professional competencies at the research location.
\end{abstract}

Keywords: Profile of competencies, Pedagogical competence, Professional competence

\section{PENDAHULUAN}

Guru adalah pendidik profesional (Undang-Undang RI Nomor 20 Tahun 2003; Undang-Undang RI Nomor 14 Tahun 2005; Peraturan Pemerintah Nomor 19 Tahun 2005; Peraturan Pemerintah RI Nomor 74 Tahun 2008). Guru yang dimaksud meliputi guru kelas, guru mata pelajaran, guru bimbingan dan konseling atau konselor, dan guru pembimbing teknologi informasi dan komunikasi (TIK) dan keterampilan komputer dan pengelolaan informasi (KKPI). Guru profesional dipersyaratkan memiliki kualifikasi akademik sesuai dengan bidang studi yang diampu serta memiliki penguasaan kompetensi berdasarkan tuntutan Undangundang Guru dan Dosen. Pengakuan guru sebagai pendidik yang profesional dibuktikan dengan sertifikat pendidik yang diperoleh melalui suatu proses sistematik yang disebut sertifikasi (Kemendikbud, 2015).

Profesional adalah pekerjaan/ kegiatan yang dilakukan oleh seseorang dan menjadi sumber penghasilan kehidupan yang memerlukan keahlian, kemahiran, atau kecakapan yang memenuhi standar mutu/ norma tertentu serta memerlukan pendidikan profesi (Undang-Undang Nomor 14 Tahun 2005). Karena guru merupakan tenaga profesional, maka guru dituntut untuk terus mengembangkan diri sesuai dengan perkembangan ilmu pengetahuan, 
perkembangan teknologi serta perkembangan seni (Kemendikbud, 2015).

Kompetensi guru dapat dimaknai sebagai seperangkat pengetahuan, keterampilan serta perilaku yang mesti dimiliki dan dihayati serta dikuasai oleh guru dalam melaksanakan tugas-tugas keprofesionalannya yang meliputi kompetensi pedagogik, kompetensi kepribadian, kompetensi sosial serta kompetensi profesional (Undang-Undang RI Nomor 14 Tahun 2005; Pujiastuti, et al., 2012; Bakri \& Raharjo, 2015; Wulandari \& Mundilarto, 2016; Dudung, 2018). Dalam penelitian ini hanya difokuskan pada kompetensi pedagogik dan profesional.

Kompetensi pedagogik merupakan kompetensi guru yang berkaitan dengan pengelolaan pembelajaran peserta didik (Penjelasan atas Undang Undang Republik Indonesia nomor 14 tahun 2005; Purwana, 2010; Bakri \& Raharjo, 2015; Saprudin, et al., 2018; Dudung, 2018). Sedangkan kompetensi profesional merupakan kompetensi guru yang berkaitan dengan keluasan serta kedalaman penguasaan materi pelajaran (Penjelasan atas Undang Undang Republik Indonesia nomor 14 tahun 2005; Sembiring, 2009; Purwana; 2010; Saprudin, et al., 2018; Dudung, 2018).

Kenyataan menunjukkan bahwa kompetensi guru khususnya guru untuk mata pelajaran fisika pada lokasi penelitian masih sangat perlu untuk ditingkatkan.

Tabel 1. Profil Kompetensi Guru Fisika pada Pelaksanaan Sertifikasi Guru (PSG Rayon 130, 2012; Saprudin, 2013; PSG Rayon 130, 2013; Saprudin, 2014)

\begin{tabular}{cccc}
\hline \multicolumn{2}{c}{$\begin{array}{c}\text { Sertifikasi Guru tahun } \\
2012\end{array}$} & \multicolumn{2}{c}{ Sertifikasi Guru tahun } \\
2013 \\
\hline UKA & UTN & UKA & UTN \\
36,25 & 45,62 & 25,60 & 55,00 \\
\hline
\end{tabular}

Berdasarkan uraian di atas, Lembaga Pendidikan Tenaga Kependidikan (LPTK) memiliki peranan penting terkait upaya mempersiapkan calon guru khususnya guru fisika profesional yang salah satunya memiliki kompetensi pedagogik dan kompetensi profesional yang baik. Oleh karena itu, sangat penting dilakukan pemetaan kompetensi pedagogik dan profesional mahasiswa calon guru fisika (MCGF) yang dapat digunakan sebagai acuan dalam merekomendasikan berbagai tindakan yang efektif dan efisien dalam rangka peningkatan kompetensi MCGF secara berkelanjutan.

\section{METODE}

Penelitian survei ini ditujukan untuk menggambarkan profil kompetensi pedagogik dan kompetensi profesional MCGF. Survei ini melibatkan 60 MCGF yang berada pada semester VI sampai semester VIII, tahun akademik 2015-2016, pada salah satu LPTK di kota Ternate, Maluku Utara, Indonesia. Sampel dipilin melalui teknik purposive sampling dengan pertimbangan kecukupan mata kuliah terkait kompetensi pedagogik dan profesional yang telah dipelajari oleh MCGF di lokasi penelitian.

Pengumpulan data penelitian dilakukan melalui tes uji kompetensi guru mata pelajaran fisika dan melalui studi dokumentasi. Analisis deskriptif kuantitatif dilakukan untuk menggambarkan profil kompetensi pedagogik dan kompetensi profesional MCGF.

\section{HASIL DAN PEMBAHASAN}

Temuan dari hasil analisis kompetensi pedagogik dan profesional MCGF dapat diuraikan secara rinci sebagai berikut.

\section{Profil Kompetensi Pedagogik Mahasiswa Calon Guru Fisika (MCGF)}

Hasil analisis data kompetensi pedagogik MCGF ditunjukkan pada Gambar 1.

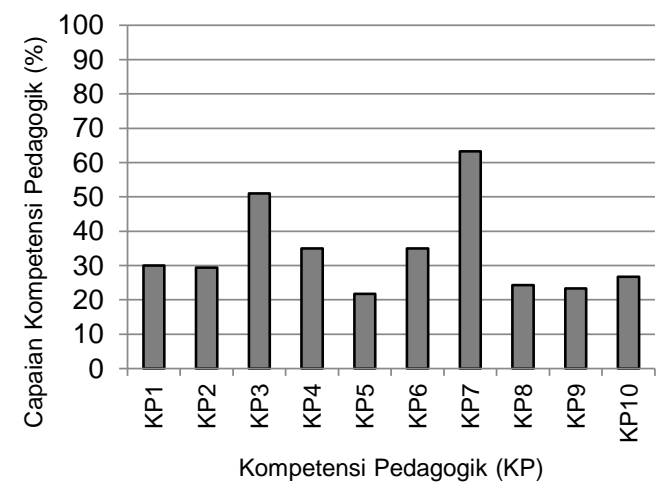

Gambar 1. Profil Kompetensi Pedagogik MCGF 
Berdasarkan Gambar 1 ditunjukkan bahwa kompetensi pedagogik MCGF secara umum dikategorikan rendah $(34,0 \%)$. Untuk kompetensi inti 1 (KP1), yakni kompetensi terkait penguasaan karakteristik peserta didik baik pada aspek fisik, aspek moral, aspek spiritual, aspek sosial, aspek kultural, aspek emosional serta aspek intelektual dapat dikategorikan rendah (30,0\%). Sebelum pelaksanaan pembelajaran, guru sebaiknya melakukan identifikasi terkait karakteristik peserta didik sehingga guru dapat merancang strategi yang mampu mengembangkan potensi mereka secara optimal, memperbaiki kelemahan peserta didik, serta memotivasi mereka untuk belajar (Wulandari \& Mundilarto, 2016).

Pada kompetensi inti 2 (KP2) yakni kompetensi terkait penguasaan teori-teori belajar serta prinsip-prinsip tentang pembelajaran yang mendidik, ditemukan pada kategori rendah $(29,4 \%)$. Pemahaman teoriteori belajar dapat dijadikan sebagai panduan guru dalam merancang serta merencanakan pembelajaran, membantu dalam memahami cara belajar peserta didik, sehingga dapat menunjang pada terselenggaranya proses pembelajaran yang lebih efektif, efisien serta produktif (Sani, 2013).

Terkait kompetensi inti 3 (KP3) yakni kompetensi terkait pengembangan kurikulum pada mata pelajaran atau bidang studi yang diampu dikategorikan sedang $(51,0 \%)$. Kurikulum perlu dikembangkan, karena kurikulum yang tidak relevan dengan perkembangan jaman serta kebutuhan masyarakat, maka lulusan yang dihasilkan merupakan lulusan yang kurang siap, oleh karena itu masyarakat akan sulit untuk menerimanya (Mansur, 2016).

Untuk kompetensi inti 4 (KP4) yakni kompetensi terkait penyelenggaraan kegiatan pembelajaran yang mendidik dapat dikategorikan rendah (35,0\%). Dewasa ini, kegiatan pembelajaran fisika tidak hanya ditujukan untuk penguasaan konsep semata, akan tetapi melalui konsep-konsep yang kita ajarkan diharapkan dapat juga melatihkan keterampilan lainnya sebagai efek iringan dari pembelajaran yang kita dilakukan. Beberapa keterampilan yang dapat dilatihkan diantaranya adalah keterampilan berpikir kritis (Saprudin, et al., 2019a; Saprudin, et al., 2019b), berpikir kreatif (Saprudin, et al., 2019b; Saprudin, et al., 2019c), ataupun keterampilan lainnya yang dipandang perlu untuk dimiliki oleh peserta didik dalam ha ini MCGF.

Kompetensi inti (KP5) yakni kompetensi terkait pemanfaatan teknologi informasi dan komunikasi (TIK) dalam pembelajaran dapat dikategorikan rendah (21,7\%). Pentingnya pemanfaatan media dalam pembelajaran, menjadikannya sebagai salah satu item penilaian khususnya pada standar proses dalam penilaian akreditasi sekolah (Rahman, et al., 2017). Berbagai ragam media pembelajaran yang dapat digunakan dalam pembelajaran fisika seperti penggunaan video pembelajaran (Abdullah, et al., 2016; Saprudin, et al., 2018), multimedia interaktif (Saprudin, et al., 2010; Saprudin, 2015; Saprudin \& Hamid, 2018a; Saprudin \& Hamid, 2018b), game (Saprudin, et al., 2017; Saprudin, 2018; Saprudin, et al., 2019d) dan gamifikasi (Saprudin, et al., 2019b). Guru juga diharapkan dapat mengembangkan kreativitasnya dalam merancang berbagai media pembelajaran dengan menggunakan bahan-bahan sederhana dan dan mudah ditemukan dalam kehidupan sehari-hari (Saprudin, et al., 2018).

Untuk kompetensi inti 6 (KP6) yakni kompetensi terkait peranan guru sebagai fasilitator dalam pengembangan dan pengaktualisasian potensi-potensi peserta didik, ditemukan pada kategori rendah $(35,0 \%)$. Pembelajaran yang dilakukan diharapkan dapat melatihkan peserta didik dalam pengambilan keputusan terkait karirnya sebagai contoh melalui program peminatan yang terfokus pada peminatan studi, karir atau pekerjaan, guru berperan penting dalam mengembangkan potensi peserta didik secara optimum (Zamroni, 2016).

Kompetensi inti 7 (KP7) yakni kompetensi terkait komunikasi yang efektif, empatik serta santun terhadap peserta didik, dapat dikategorikan tinggi (63,3\%). Keterampilan komunikasi merupakan salah 
satu keterampilan abad 21 serta merupakan salah satu faktor penting dalam problem solving (Erwin, et al., 2019).

Untuk kompetensi inti 8 (KP8) yakni kompetensi terkait penyelenggaraan penilaian serta evaluasi proses dan evaluasi hasil belajar peserta didik, ditemukan pada kategori rendah $(24,3 \%)$. Guru diharapkan dapat melakukan penilaian autentik. Hasil penelitian menunjukkan bahwa penilaian autentik dapat meningkatkan motivasi belajar, partisipasi dan hasil belajar (Maruf \& Rahim, 2013), serta dapat bermanfaat dalam memonitor kemajuan belajar peserta didik (Yuliati, 2017).

Terkait kompetensi inti 9 (KP9) yakni kompetensi terkait pemanfaatan hasil penilaian dan evaluasi terhadap proses serta hasil belajar peserta didik yang ditujukan untuk kepentingan pembelajaran, dikategorikan rendah $(23,3 \%)$. Hasil penilaian dan evaluasi dapat dimanfaatkan untuk mendiagnosis kesulitan/ kekurangan/ kelemahan, pengelompokkan dan penempatan (organisasi kelas), motivasi serta promosi, acuan dalam merencanakan program pembelajaran, bimbingan dan program remedial serta sebagai bahan pelaporan hasil belajar peserta didik (Akhsanti, 2014; Pauji, et al., 2016).

Untuk kompetensi inti 10 (KP10) yakni kompetensi terkait tindakan-tindakan reflektif yang ditujukan untuk meningkatkan kualitas pembelajaran, dapat dikategorikan rendah $(26,7 \%)$. Refleksi merupakan prasyarat agar dapat melakukan perbaikan-perbaikan dalam rangka peningkatan kualitas proses dan hasil pembelajaran (Julaeha, 2009).

\section{Profil Kompetensi Profesional Mahasiswa Calon Guru Fisika (MCGF)}

Hasil analisis data kompetensi profesional MCGF ditunjukkan pada Tabel 2. Profil kompetensi profesional MCGF secara umum dikategorikan rendah $(25,8 \%)$.

Tabel 2. Profil Kompetensi Profesional MCGF untuk Setiap Kemampuan Uji

\begin{tabular}{|c|c|}
\hline Kemampuan Uji & $\begin{array}{c}\text { Persentase } \\
(\%)\end{array}$ \\
\hline $\begin{array}{l}\text { 1. Menyebutkan hasil pengukuran } \\
\text { dengan mikrometer sekrup }\end{array}$ & 27 \\
\hline 2. Menentukan luas suatu bidang & 37 \\
\hline
\end{tabular}

\begin{tabular}{|c|c|}
\hline Kemampuan Uji & Persentase \\
\hline $\begin{array}{l}\text { kertas berdasarkan hasil } \\
\text { pengukuran panjang dan lebar } \\
\text { dengan menggunakan jangka } \\
\text { sorong }\end{array}$ & \\
\hline $\begin{array}{l}\text { 3. Menentukan perbandingan } \\
\text { jarak yang ditempuh oleh } \\
\text { kedua orang jika diketahui } \\
\text { gaya, kecepatan dan waktu }\end{array}$ & 45 \\
\hline $\begin{array}{l}\text { 4. Menentukan besarnya } \\
\text { percepatan dan tegangan tali } \\
\text { pada suatu sistem katrol }\end{array}$ & 38 \\
\hline 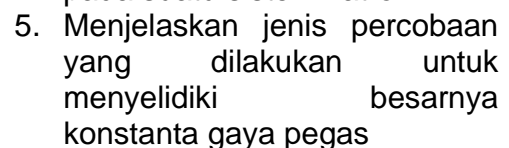 & 25 \\
\hline $\begin{array}{l}\text { 6. Menentukan besarnya energi } \\
\text { suatu kuanta cahaya dengan } \\
\text { panjang gelombang tertentu }\end{array}$ & 27 \\
\hline $\begin{array}{l}\text { 7. Menentukan } \\
\text { gelombang partikel dengan } \\
\text { menerapkan hipotesa De } \\
\text { Broglie }\end{array}$ & 25 \\
\hline $\begin{array}{l}\text { 8. Menentukan pernyataan yang } \\
\text { paling tepat berdasarkan grafik } \\
\text { hubungan intensitas }(I) \text { dan } \\
\text { panjang gelombang }(\lambda) \text { pada } \\
\text { peristiwa radiasi benda hitam }\end{array}$ & 15 \\
\hline $\begin{array}{l}\text { 9. Menunjukkan grafik yang } \\
\text { menunjukkan besarnya gaya } \\
\text { archimedes (gaya apung) pada } \\
\text { batu dan kedalaman batu } \\
\text { tersebut dalam air }\end{array}$ & 23 \\
\hline $\begin{array}{l}\text { 10. Menentukan ketinggian suatu } \\
\text { daerah yang diketahui tekanan } \\
\text { udara di daerah tersebut }\end{array}$ & 35 \\
\hline $\begin{array}{l}\text { 11. Menentukan tekanan suatu } \\
\text { daerah yang diketahui } \\
\text { ketinggiannya }\end{array}$ & 45 \\
\hline $\begin{array}{l}\text { 12. Menentukan kecepatan satelit } \\
\text { dengan menerapkan konsep } \\
\text { gaya gravitasi dan gaya } \\
\text { sentripugal }\end{array}$ & 12 \\
\hline $\begin{array}{l}\text { 13. Menentukan besarnya panjang } \\
\text { gelombang dan kecepatan } \\
\text { gelombang berdasarkan } \\
\text { persamaan gelombang yang } \\
\text { disajikan }\end{array}$ & 33 \\
\hline $\begin{array}{l}\text { 14. Menyebutkan sifat-sifat } \\
\text { gelombang elektromagnetik }\end{array}$ & 32 \\
\hline $\begin{array}{l}\text { 15. Menentukan } \\
\text { frekuensi yang didengar } \\
\text { pengamat berdasarkan efek } \\
\text { doppler }\end{array}$ & 28 \\
\hline $\begin{array}{l}\text { 16. Menentukan banyaknya lilitan } \\
\text { sekunder pada transformator } \\
\text { step up }\end{array}$ & 17 \\
\hline $\begin{array}{l}\text { 17. Menjelaskan konsep fisika } \\
\text { yang dipergunakan pada alat } \\
\text { dinamo }\end{array}$ & 50 \\
\hline $\begin{array}{l}\text { 18. Menentukan arah gerak } \\
\text { sebuah muatan listrik yang } \\
\text { memasuki ruang dengan arah } \\
\text { medan listrik tegak lurus } \\
\text { dengan arah kecepatannya }\end{array}$ & 0 \\
\hline
\end{tabular}




\begin{tabular}{|c|c|}
\hline Kemampuan Uji & $\begin{array}{c}\text { Persentase } \\
(\%)\end{array}$ \\
\hline $\begin{array}{l}\text { 19. Menentukan arah gerak suatu } \\
\text { partikel yang bergerak pada } \\
\text { ruang dengan medan magnet } \\
\text { dengan arah tertentu }\end{array}$ & 15 \\
\hline $\begin{array}{l}\text { 20. Menentukan kecepatan rata- } \\
\text { rata dan percepatan rata-rata } \\
\text { berdasarkan gambar yang } \\
\text { disajikan }\end{array}$ & 13 \\
\hline $\begin{array}{l}\text { 21. Menentukan karakteristik dari } \\
\text { gerak parabola }\end{array}$ & 47 \\
\hline $\begin{array}{l}\text { 22. Mendeskripsikan gerak suatu } \\
\text { benda berdasarkan grafik } \\
\text { kecepatan terhadap waktu }\end{array}$ & 0 \\
\hline $\begin{array}{l}\text { 23. Menentukan waktu dan tempat } \\
\text { kedua orang bertemu jika } \\
\text { jarak, kelajuan dan waktu } \\
\text { kedua orang tersebut diketahui }\end{array}$ & 40 \\
\hline $\begin{array}{l}\text { 24. Menyebutkan hasil pengukuran } \\
\text { dengan menggunakan } \\
\text { amperemeter }\end{array}$ & 28 \\
\hline $\begin{array}{l}\text { 25. Menentukan panjang kawat } \\
\text { yang diperlukan pada sebuah } \\
\text { alat pemanas dengan } \\
\text { hambatan tertentu dan } \\
\text { dihubungkan pada tegangan } \\
\text { tertentu }\end{array}$ & 13 \\
\hline $\begin{array}{l}\text { 26. Menentukan daya pada } \\
\text { sebuah lampu yang dipasang } \\
\text { pada tegangan tertentu }\end{array}$ & 22 \\
\hline $\begin{array}{l}\text { 27. Menentukan jarak suatu } \\
\text { muatan dari muatan lainnya } \\
\text { jika diketahui resultan gaya } \\
\text { listrik pada suatu muatan } \\
\text { adalah nol }\end{array}$ & 15 \\
\hline $\begin{array}{l}\text { 28. Menentukan perbandingan dua } \\
\text { buah muatan jika diketahui } \\
\text { kuat medan listrik di suatu titik } \\
\text { adalah nol }\end{array}$ & 20 \\
\hline $\begin{array}{l}\text { 29. Menyebutkan kelemahan } \\
\text { model atom Rutherford }\end{array}$ & 40 \\
\hline $\begin{array}{l}\text { 30. Menentukan jumlah elektron, } \\
\text { jumlah netron dan jumlah } \\
\text { proton dari suatu atom }\end{array}$ & 22 \\
\hline $\begin{array}{l}\text { 31. Menerapkan konsep } \\
\text { interferensi untuk menentukan } \\
\text { jarak antar kedua celah }\end{array}$ & 0 \\
\hline $\begin{array}{l}\text { 32. Menyebutkan makna dari } \\
\text { cahaya mengalami polarisasi }\end{array}$ & 8 \\
\hline $\begin{array}{l}\text { 33. Menentukan besarnya jarak } \\
\text { lensa okuler harus digeser } \\
\text { agar mata berakomodasi } \\
\text { secara } \\
\text { berdasarkan gambar hasil } \\
\text { pengamatan } \\
\text { mikroskop }\end{array}$ & 27 \\
\hline $\begin{array}{l}\text { 34. Menyebutkan ke tiga jenis } \\
\text { sinar radioaktif berdasarkan } \\
\text { gambar lintasannya ketika } \\
\text { melewati medan magnet } \\
\text { dengan arah tertentu }\end{array}$ & 15 \\
\hline $\begin{array}{l}\text { 35. Menentukan waktu paruh } \\
\text { suatu zat radioaktif }\end{array}$ & 28 \\
\hline $\begin{array}{l}\text { 36. Menghitung besarnya laju kalor } \\
\text { pada suatu fenomena konduksi }\end{array}$ & 20 \\
\hline
\end{tabular}

\begin{tabular}{lc}
\hline Kemampuan Uji & $\begin{array}{c}\text { Persentase } \\
(\%)\end{array}$ \\
\hline 37. Menghitung besarnya & 25 \\
perbandingan antara jumlah \\
kalor yang diperlukan oleh dua \\
jenis zat dengan kalor jenis, \\
massa, serta kenaikan suhu \\
tertentu \\
38. Menentukan besarnya kalor \\
yang diperlukan pada peristiwa \\
peleburan es yang memiliki \\
massa serta suhu tertentu \\
39. Menentukan besarnya suhu \\
tandon kalor bersuhu tinggi \\
pada mesin siklus carnot \\
40. Menentukan besarnya efisiensi \\
mesin carnot berdasarkan \\
gambar yang disajikan
\end{tabular}

\section{PENUTUP}

Berdasarkan hasil analisis data menunjukkan bahwa kompetensi pedagogik dan profesional mahasiswa calon guru fisika masih dikategorikan rendah dengan rerata persentase masing-masing capaian kompetensi sebesar $34,0 \%$ dan $25,8 \%$.

\section{UCAPAN TERIMA KASIH}

Penulis mengucapkan terima kasih pada semua pihak yang telah membantu penelitian ini terutama kepada Mahasiswa Program Studi Pendidikan Fisika yang telah berpartisipasi dalam penelitian ini.

\section{REFERENSI}

Abdullah, I. H., Haerullah, A., \& Saraha, A. R. (2016). Pengembangan Media Video Tutorial Model Pembelajaran Berbasis Masalah Pada Materi Kalor. Edukasi: Jurnal Pendidikan, 14(2).

Akhsanti, M. S. (2014). Pemanfaatan Hasil Evaluasi Pembelajaran dalam Pengembangan Program Pembelajaran Anak Usia Dini. BELIA: Early Childhood Education Papers, 3(2).

Bakri, F., Raharjo, S.B. (2015). Analisis Hasil 
Uji Kompetensi Guru Fisika. Jurnal Penelitian \& Pengembangan Pendidikan Fisika (JPPPF), 1(1), 9196.

Dudung, A. (2018). Kompetensi Profesional Guru. JKKP (Jurnal Kesejahteraan Keluarga Dan Pendidikan), 5(1), 9-19.

Erwin, E., Rustaman, N. Y., Firman, H., \& Ramalis, T. R. (2019). Instrumen Asesmen Pedagogical Content Knowledge dalam Konteks Pengembangan Keterampilan Komunikasi Saintifik pada Pembelajaran Fisika. Titian IImu: Jurnal IImiah Multi Sciences, 11(2), 102-110.

Julaeha, S. (2009). Pembimbingan refleksi pembelajaran dalam PKP: Suatu analisis empiris pada program $\mathrm{S} 1$ PGSD-UT. Jurnal Pendidikan, 10(2), 67-77.

Kemendikbud. (2015). Sertifikasi Guru Dalam Jabatan Tahun 2015; Buku 4, RambuRambu Pelaksanaan Pendidikan Dan Latihan Profesi Guru (PLPG). Jakarta : Kementerian Pendidikan dan Kebudayaan

Kemendikbud. (2015). Pedoman Pelaksanaan Uji Kompetensi Guru. Jakarta : Kementerian Pendidikan dan Kebudayaan

Mansur, R. (2016). Pengembangan Kurikulum Pendidikan Agama Islam Multikultural (Suatu Prinsip-Prinsip Pengembangan). Vicratina: Jurnal Pendidikan Islam, 1(2).

Maruf, M., \& Rahim, A. L. (2013). Pengembangan Perangkat Penilaian Autentik Dalam Pembelajaran Fisika Untuk Meningkatkan Motivasi, Partisipasi Dan Hasil Belajar Fisika Siswa Kelas $X$ SMA Negeri 1 Pangkajene. Jurnal Pendidikan Fisika, 1(3), 252-263.

Pauji, R., Trisna, B. N., \& Atsnan, M. F. (2016). Pemanfaatan hasil evaluasi pembelajaran matematika SMA di kota Banjarmasin. Math Didactic: Jurnal Pendidikan Matematika, 2(3), 164-170.

Penjelasan atas Undang-Undang Republik Indonesia Nomor 14 tahun 2005 tentang Guru dan Dosen

Peraturan Pemerintah Republik Indonesia Nomor 19 Tahun 2005 Tentang Standar Nasional Pendidikan

Peraturan Pemerintah Republik Indonesia Nomor 74 Tahun 2008 Tentang Guru

PSG Panitia Sertifikasi Guru Rayon 130. (2012). Laporan Pelaksanaan Sertifikasi Guru Dalam Jabatan Tahun 2012; Buku 1 (Unpublished). Universitas Khairun, Ternate

PSG Panitia Sertifikasi Guru Rayon 130. (2013). Laporan Pelaksanaan Sertifikasi Guru Dalam Jabatan Tahun 2013; Buku 1 (Unpublished). Universitas Khairun, Ternate

Pujiastuti, E., Raharjo, T. J., \& Widodo, A. T. (2012). Kompetensi profesional, pedagogik guru IPA, persepsi siswa tentang proses pembelajaran, dan kontribusinya terhadap hasil belajar IPA di SMP/MTs Kota Banjarbaru. Innovative Journal of Curriculum and Educational Technology, 1(1).

Purwana, U. (2010). Profil kompetensi pedagogik guru IPA-fisika SMP dan MTs di wilayah Paseh Kabupaten Sumedang melalui kegiatan lesson study berbasis MGMP. Bandung: FPMIPA UPI.

Rahman, M. H., Saprudin, S., Mubarak, H., \& Hamid, F. (2017). Evaluasi Program IbM Pendampingan Penyusunan Borang Akreditasi Bagi Sekolah Dasar di Kota Ternate. Titian IImu: Jurnal IImiah Multi Sciences, 9(2), 59-65.

Sani, R. A. (2013). Inovasi pembelajaran. Jakarta: Bumi Aksara. 
Saprudin. (2013). Profil Kompetensi Guru Bidang Studi Fisika pada Pelaksanaan Sertifikasi Guru dalam Jabatan Tahun 2012 di Provinsi Maluku Utara. Jurnal Omega, 2(1)

Saprudin. (2014). Analisis Capaian Kompetensi Guru Bidang Studi Fisika pada Pelaksanaan Sertifikasi Guru dalam Jabatan Tahun 2013 di Provinsi Maluku Utara. In Prosiding Seminar Kontribusi Fisika 2014 (SKF 2014)

Saprudin, S. Efektivitas Penerapan Model Kooperatif STAD Berbasis Multimedia untuk Meningkatkan Penguasaan Siswa SMA terhadap Kemampuan yang Diujinasionalkan MataPelajaran Fisika di Maluku Utara. ProsidingSNIPS2015.

Saprudin, S. (2018). Analisis Kesiapan dan Strategi Monitoring Evaluasi Program Pengembangan Perkuliahan Gelombang dan Optik Berbasis Game. JIPFRI (Jurnal Inovasi Pendidikan Fisika Dan Riset IImiah), 2(1), 28-37.

Saprudin, S., Haerullah, A. H., Abdullah, I. H., Saraha, A. R., \& Hamid, F. (2018). Pengembangan Media Video Tutorial Model Discovery Learning Materi Tekanan Hidrostatis. In Prosiding Seminar Kontribusi Fisika (Vol. 2017, pp. 300-304).

Saprudin, S., \& Hamid, F. (2018, November). Penggunaan multimedia interaktif model drill and practice materi fluida dinamis untuk meningkatkan penguasaan konsep siswa Sekolah Menengah Atas (SMA). In Prosiding Seminar Nasional Fisika (Ejournal) (Vol. 7, pp. SNF2018-PE).

Saprudin, S., \& Hamid, F. (2018). Efektivitas penggunaan multimedia interaktif materi kalor berorientasi peta kompetensi siswa Sekolah Menengah Atas. Titian IImu: Jurnal IImiah Multi Sciences, 10(1), 29-38.

Saprudin, S., Liliasari, L., \& Prihatmanto, A. S.
(2017, September). Pre-Service Physics Teachers' Concept Mastery and the Challenges of Game Development on Physics Learning. In Journal of Physics: Conference Series (Vol. 895, No. 1, p. 012109). IOP Publishing.

Saprudin, S., Liliasari, L., Prihatmanto, A. S., \& Setiawan, A. (2018). The Design of Media on Two-Lens System Experiment (MTLSE) for Pre-service Physics Teachers. Jurnal Penelitian \& Pengembangan Pendidikan Fisika, 4(2), 91-100.

Saprudin, S., Liliasari, S., Prihatmanto, A. S., \& Setiawan, A. (2019, February). Preservice physics teachers' thinking styles and its relationship with critical thinking skills on learning interference and diffraction. In Journal of Physics: Conference Series (Vol. 1157, No. 3, p. 032029). IOP Publishing.

Saprudin, S., Liliasari, L., Prihatmanto, A. S., \& Setiawan, A. (2019). The Potential of Gamification in Developing PreService Physics Teachers' Critical and Creative Thinking Skills. Omega: Jurnal Fisika dan Pendidikan Fisika, 5(1), 7-7.

Saprudin, S., Liliasari, S., Prihatmanto, A. S., \& Setiawan, A. (2019, February). Profile of pre-service physics teachers' creative thinking skills on wave and optics course. In Journal of Physics: Conference Series (Vol. 1157, No. 3, p. 032030). IOP Publishing.

Saprudin, S., Liliasari, L., Setiawan, A., \& Prihatmanto, A. (2019). The effectiveness of using digital game towards students' academic achievement in small and large classes: A comparative research. International Journal of Learning, Teaching and Educational Research, 18(12), 196-210.

Saprudin, Sutarno, Liliasari. 2010. Developing Generic Science Skills Of Prospective Teacher Through Offline and Online 
8 JIPFRI (Jurnal Inovasi Pendidikan Fisika dan Riset IImiah), Vol. 4 No. 1, Mei 2020

Interactive Multimedia in Physics
Learning. Proceding of the 4th
International Conference on Teacher;
Join Conference UPI \& UPSI
Bandung. Indonesia 8-10 November
2010.

Sembiring, M. Gorky. (2009). Mengungkap Rahasia dan Tips Manjur Menjadi Guru Sejati. Yogyakarta: Best Publisher

Undang-Undang Republik Indonesia Nomor 20 Tahun 2003 Tentang Sistem Pendidikan Nasional

Undang-Undang Republik Indonesia Nomor 14 Tahun 2005 Tentang Guru dan Dosen

Wulandari, R. W., \& Mundilarto, M. (2016). Kompetensi Pedagogik Dan Profesional Guru Fisika Dalam Melaksanakan Pendekatan Saintifik Di SMAN Sleman. Jurnal Pendidikan Fisika dan Keilmuan (JPFK), 2(2), 92104.

Yuliati, L. (2017). Asesmen Autentik dalam Active Learning untuk Memonitor Kemajuan Belajar Calon Guru Fisika. JPPS (Jurnal Penelitian Pendidikan Sains), 2(1), 120-126.

Zamroni, E. (2016). Urgensi career decision making skills dalam penentuan arah peminatan peserta didik. Jurnal Konseling Gusjigang, 2(2). 